\title{
Purchase Behavior and Satisfaction of Online-only Brand Cosmetics
}

Jin-A Kim, Yun-Kyoung Oh ${ }^{*}$

Department of Cosmetology, Changshin University, Changwon-si, Gyeongsangnam-do, Korea

\author{
*Corresponding author: Yun-Kyoung Oh, \\ Department of Cosmetology, Changshin \\ University, 262 Palyongro, Masan Hoewon-gu, \\ Changwon-si, Gyeongsangnam-do 51352, Korea \\ Tel.: +82552501212 \\ Fax: +82552501215 \\ Email: yk212@cs.ac.kr
}

Received July 6, 2017

Revised October 19, 2017

Accepted October 25, 2017

Published March 30, 2018

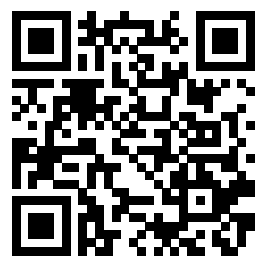

\begin{abstract}
Purpose: This study aims to provide basic information on consumer marketing in the online cosmetics market by analyzing the sales characteristics of online-only cosmetics brands and identifying the factors influencing consumers' purchasing and repurchasing patterns. Methods: Six brands were selected through a keyword search and awareness survey, and their sales characteristics were analyzed from their homepages. The questionnaire surveyed 200 women in their 20 s and 30s in Busan and Gyeongsangnam-do to investigate their cosmetics purchase pattern, purchase satisfaction, and repurchase intention. The collected data were analyzed by frequency analysis, descriptive statistics, factor analysis, and regression analysis using the SPSS statistical program. Results: First, online-only cosmetic brands often had featured products, which were highlighted and marketed through easy and characteristic product names or through various events. Second, we examined the purchasing patterns for the products of online-only cosmetics brands. Our findings showed that basic cosmetics and base makeup products were the main purchases. However, the average purchase amount or repurchase rate for the same product was low. Third, we identified four components of purchase satisfaction for online-only cosmetics brands: service and quality, product assortment, ease of use, and economy. Of these, ease of use was correlated with the highest purchase satisfaction and significant influence on repurchase intention. Conclusion: Trust and satisfaction in the quality and service of online-only cosmetics brands must be increased by improving the convenience of accessing the homepage, ordering process, and delivery information. This can be expected to have a positive impact on repurchases.
\end{abstract}

Keywords: Online-only brand, Cosmetics, Purchase behavior, Repurchase intention, Satisfaction

\section{Introduction}

정보기술의 발달과 인터넷의 확산은 전자상거래의 급속한 성 장을 야기하고 산업구조 및 소비생활의 변화를 초래하였다. 전 자상거래는 컴퓨터를 매개로 한 네트워크를 통해 상품 또는 서 비스에 대한 구매 및 판매가 이루어지는 방식으로 통계청 보도 자료에 의하면 2003년 314.1조원이었던 전자상거래 총 거래액 은 2013년 4/4분기에 1,204.1조원으로 10년 사이 4배 가까이 성장해 보편적인 상거래방식이 되어가고 있다. 특히 온라인쇼 핑몰을 통한 전자상거래는 모바일산업의 성장과 더불어 2017 년 6조 325억원에 달하고 있다(KOSIS, 2014).
화장품은 소비자의 촉감을 필요로 하는 제품(Rosen \& Howard, 2000)으로 온라인 거래에 한계점이 있는데도 불구하 고 높은 성장세를 나타내고 있다. 화장품의 온라인 구매는 공 간과 시간의 제약을 받지 않아 이동 및 탐색 비용이 절감되고 제품과 가격의 비교가 용이하며 협상이나 인적 거래의 부담감 이 적다는 장점이 있고, 의류 상품 등과 달리 동일 제품을 지속 적으로 구매할 수 있다는 점에서 두드러지는 성장세를 나타낸 다고 할 수 있다. 국내 화장품 시장은 1970 년 방문판매를 시작 으로 80 년대 화장품 전문점이 나타났고, 90 년대에는 화장품 할 인전문점이 출현하였으며 90년대 중 후반에 TV 홈쇼핑과 인 터넷 쇼핑몰이 등장하면서 온라인 유통경로가 급성장하였다 
(Chun et al., 2013). 온라인을 통한 화장품 판매처는 화장품 외 여러 상품을 일괄 구매할 수 있는 종합몰과 주된 상품군 만 을 구성하여 판매하는 전문몰로 나눌 수 있으며 유통 경로에 따 라 온라인을 통해서만 상품을 판매하는 온라인 전용몰, 온라인 을 통한 상거래뿐 아니라 오프라인 판매를 병행하는 온라인.오 프라인 병행몰로 나눌 수 있다. 최근에는 온라인에서만 판매하 고 있는 온라인전용 브랜드 화장품이 생겨나면서 온라인 거래 의 전문성을 강화하고 있다.

온라인 시장은 진입 장벽이 낮은 반면 치열한 경쟁에 부딪 혀 안정적인 정착에 이르기까지 어려움이 많다. 온라인전용 브 랜드 및 온라인 소비자의 특성은 오프라인 시장과는 차이가 클 것으로 예상되며 목표 고객의 특성에 적합한 마케팅 전략이 필 요할 것으로 생각된다. 또한 소비자의 구매 만족은 구매 후 태 도와 브랜드 충성도에 영향을 미치는데(Hellier et al., 2003; Szymanski \& Hise, 2000), 온라인전용 화장품 브랜드에 대 한 만족이 재구매에 미치는 영향을 검토함으로써 온라인에서 판매하고 있는 화장품의 구매 향상을 위한 시사점을 제시할 수 있을 것이다. 이와 관련하여 온라인 쇼핑몰의 소비자 구매행 동(Kim et al., 2000; Kim \& Ha, 2010; Lee \& Kim, 2006; Nam, 2014; Oh \& Lee, 2012)과 온라인 쇼핑몰 속성(Kim \&
Ko, 2016; Seo, 2014; Shin \& Kim, 2014), 온라인 쇼핑몰의 시장 세분화(An \& Lee, 2015; Kim \& Oh, 2009; Lee, 2008) 에 관한 연구들이 활발히 진행되고 있지만 온라인전용 브랜드 화장품의 현황이나 구매 특성 및 구매 만족에 관한 연구는 매우 부족한 실정이다.

따라서 이 연구는 온라인전용 브랜드 화장품의 판매 특성을 알아보고 소비자의 구매행태 및 만족도 요인, 재구매 영향요인 을 파악함으로써 온라인 화장품 시장의 소비자 마케팅에 대한 기초자료로 제공하고자 한다.

\section{Methods}

\section{1. 온라인전용 브랜드 화장품의 선정}

온라인전용 브랜드 화장품은 오프라인 매장이 없고 오직 온 라인으로만 판매, 홍보하는 브랜드로 조사 대상 브랜드는 다음 의 방법으로 선정하였다. 우선 포털 사이트에서 '온라인 화장 품', '인터넷 화장품' 등의 키워드를 검색하여 224 개의 브랜드 를 추출하였다. 이 중 오프라인 매장을 운영하고 있는 브랜드, 화장품 외 다른 상품을 팔고 있는 브랜드를 제외하였으며, 브

Table 1. Comparison of sales characteristics of online-only brand cosmetics

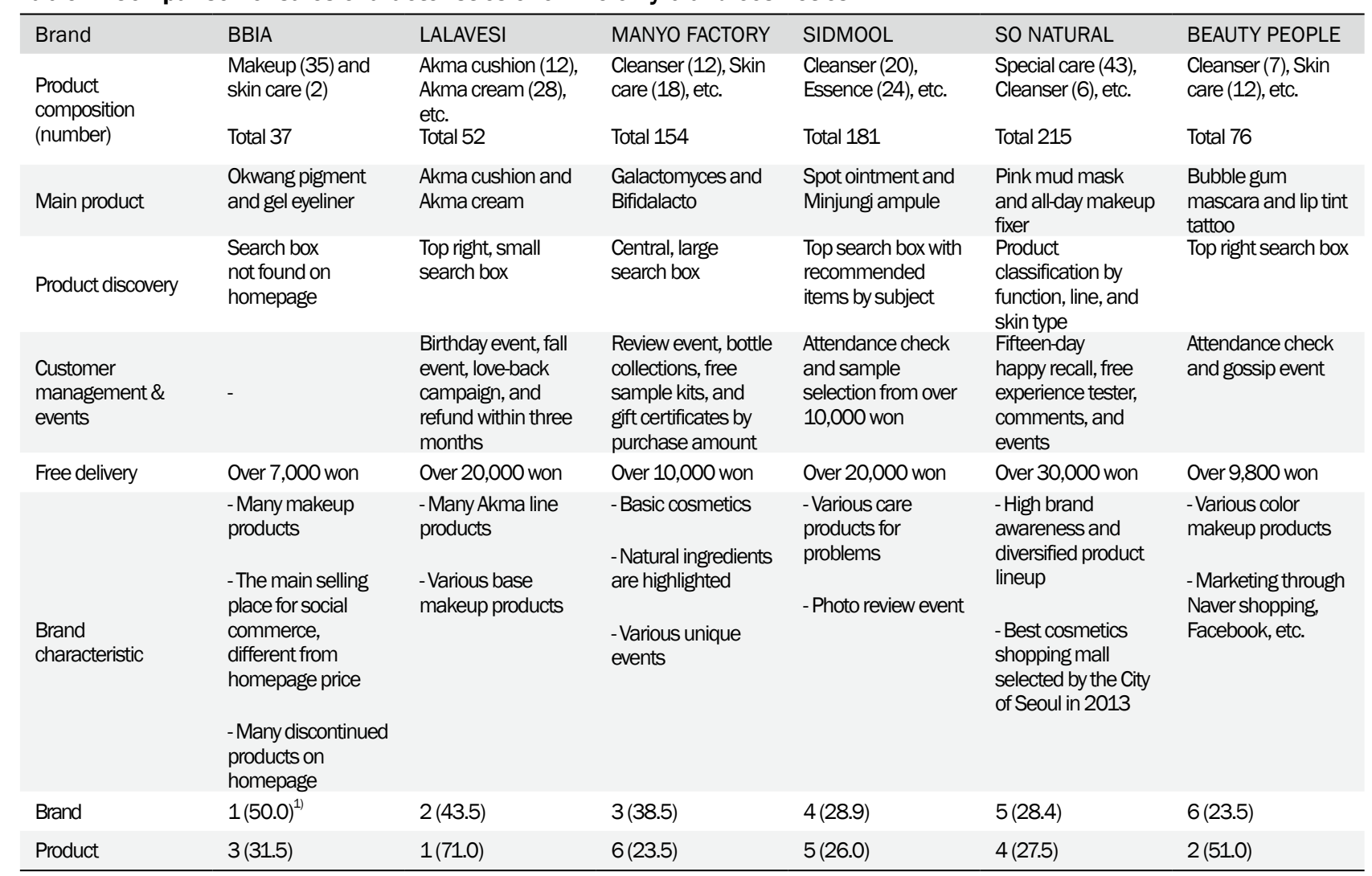

${ }^{1)}$ Awareness ranking (\%) 
랜드에 대한 소비자의 평가를 위해 인지도를 고려하였다. 인지 도는 먼저 ‘랭키닷컴’에서 1-100위 브랜드를 조사하였고 인터넷 검색결과 선정된 브랜드와 랭키닷컴 순위에 중복되어 있는 20 개의 브랜드를 대상으로 미용전공 여대생 60 명에게 인지도 설 문조사를 실시하였다. 조사결과 $20 \%$ 이상의 인지도를 나타낸 6 개의 브랜드가 최종 선정되었다.

\section{2. 온라인전용 브랜드 화장품의 판매특성 분석}

온라인전용 브랜드 화장품의 판매특성을 분석하기 위하여 2016년 9월 2일부터 9월 10일까지 각 브랜드의 홈페이지 내용 을 조사하였으며 분석 내용은 상품구성, 대표제품, 제품검색, 고객관리 및 이벤트, 배송비 무료기준, 브랜드 주요 특성의 6 개 항목이다.

\section{3. 설문조사}

온라인전용 화장품 구매자의 구매행태와 만족도, 재구매 영 향요인을 파악하기 위하여 설문조사를 실시하였다. 조사대상은 온라인을 통한 화장품 구매가 활발할 것으로 판단되는 20-30 대 여성으로, 부산.경상남도 지역 200명을 대상으로 2016년 9 월 15 일부터 10 월 5 일까지 실시하였으며 선행연구(Ju \& Ahn, 2010; Lee, 2014)를 참고로 하여 온라인 화장품 구매현황 및 구매행태와 관련된 6 문항, 구매 후 만족도 20 문항, 재구매의도 5 문항, 브랜드와 대표 제품 인지도 2 문항으로 구성하였다.

조사 대상자의 일반적인 특성은 연령의 경우 20 대가 112 명 (56.0\%), 30대가 88명(44.0\%)이었으며 미혼이 151 명(75.5\%), 기혼이 49 명(24.5\%)이었다. 직업은 학생이 102 명(51.0\%), 서 비스/판매직이 34명(17.0\%), 주부가 23명(11.5\%), 사무직이 21 명(10.5\%), 전문직이 15 명 $(7.5 \%)$, 기타가 5 명(2.5\%)이었다.

\section{4. 자료분석}

수집된 자료는 SPSS 18.0 통계프로그램(IBM, USA)으로 분 석하였으며 빈도분석, 기술통계, 요인분석, 회귀분석을 실시하 였다.

\section{Results and Discussion}

\section{1. 온라인전용 브랜드 화장품의 판매특성 비교}

온라인전용 브랜드 화장품의 홈페이지를 조사, 분석하고 설문지를 통해 인지도를 알아본 결과는 Table 1 과 같다. 먼 저 브랜드의 인지도는 중복 응답이 가능하도록 하였는데 삐아 (50.0\%), 라라베시(43.5\%), 마녀공장(38.5\%), 시드물(28.9\%), 쏘내추럴(28.4\%), 뷰티피플(23.5\%) 순으로 나타났다. 각 브랜 드의 대표제품 인지도는 라라베시에서 출시된 제품들, 악마쿠
션과 악마크림(71.0\%)이 가장 높았으며 뷰티피플의 버블껌 마 스카라와 립틴트 타투(51.0\%), 삐아의 오광 피그먼트와 젤아이 라이너(31.5\%), 쏘내추럴의 핑크 머드 마스크와 올데이 메이크 업 픽서(27.5\%), 시드물의 스팟연고와 민중기 앰플(26.0\%), 마 녀공장의 갈락토미세스, 비피다락토 $(23.5 \%)$ 순이었다.

판매하고 있는 상품은 쏘내추럴이 215종으로 가장 많았으 며 시드물(181종), 마녀공장(154종), 뷰티피플(76종), 라라베 시(52종), 삐아(37종) 순으로 많았다. 홈페이지에서 제품을 검 색할 때 삐아는 검색창이 홈에 바로 없었으며 라라베시는 오른 쪽 상단에 작은 검색창이 있었다. 마녀공장은 중앙에 큰 검색 창이 있었고 시드물은 상단에 검색창이 있으며 대상별 추천상 품을 제시하고 있었다. 쏘내추럴의 경우 오른쪽 상단에 검색창 이 있으며 기능별, 라인별, 피부타이별로 제품을 분류하였고 뷰티피플은 오른쪽 상단에 검색창이 있었다. 무료 배송이 가능 한 구매액은 쏘내추럴이 30,000 원 이상, 라라베시, 시드물이 20,000 원 이상이었고, 마녀공장이 10,000 원 이상, 뷰티피플이 9,800 원, 삐아가 7,000 원 이상이었다. 각 브랜드별 특성을 살 펴보면 삐아는 색조 중심의 브랜드이며 소셜커머스가 주요 판 매처로 온라인 상에서 가격이 다른 경우가 있었고 홈페이지 상 에 단종 상품이 많았다. 라라베시는 베이스 메이크업 제품이 다양하였고 홈페이지의 카테고리가 영어로 구성되어 있으며 생 일, 가을신상 이벤트, 러브백 캠페인 등의 이벤트를 실시하고 있었다. 마녀공장은 기초화장품, 향수제품이 다양하며 공병모 으기, 샘플킷 등 독특한 이벤트를 진행하고 있었다. 시드물은 트러블케어 제품이 다양하며 대상별 추천상품을 제안하고 있 다. 쏘내추럴은 2013년 서울시 선정 최우수 쇼핑몰로 상품 구 성이 다양하며 페이백, 해피리콜과 같은 이벤트를 진행하고 있 었다. 마지막으로 뷰티피플은 색조 메이크업 제품 위주로 구성 되어 있으며 네이버쇼핑, 페이스북을 통한 마케팅이 활발하였 다.

이와 같이 온라인전용 화장품은 브랜드의 인지도와 제품의 인지도에 차이가 있었으며 제품의 이름과 특징을 부각하는 경 우가 많았다. 오프라인 제품에 비해 새로운 제품이 다양하게 출시되어 제품의 종류가 많았으며 브랜드별로 특징적인 홍보 및 이벤트를 실시하였다.

\section{2. 온라인전용 브랜드 화장품의 구매행태}

20-30대 여성들의 온라인전용 브랜드 화장품의 구매행태 를 알아본 결과(Table 2), 화장품을 구매할 때 고려사항은 주 로 품질 및 기능(71.0\%)이었으며 가격(16.5\%)과 상품의 인지도 (5.0\%) 순으로 나타났다. 동일제품 구매성향은 가끔 다른 제품 을 구입하거나(47.5\%), 대체로 동일한 제품을 구입(29.0\%)하 는 경우가 많았다. 연평균 구매 금액은 5 만원 이하(44.0\%), 10 만원 이하(26.5\%)가 많았으며, 화장품 구매 중 온라인을 이용 
한 구매비율은 10\% 미만(43.5\%), 10-30\% 미만(33.5\%)이 많 았다. 브랜드를 알게 된 경로는 까페나 블로그와 같은 인터넷 (54.5\%), social networking service (SNS; 27.5\%)를 통해서 가 많았으며, 주로 구매하는 제품은 기초화장품(28.0\%)이 가장 많았고 베이스 메이크업(27.0\%)과 포인트 메이크업(26.5\%) 제 품도 비슷하게 나타났다.

온라인을 통한 화장품 구매에 관련된 선행연구와 결과를 비 교해 보면 SeO (2014)는 20대 여자대학생의 화장품 구입 횟 수는 1 년에 3 회 미만이 가장 많았고 $(55.7 \%)$, 메이크업 제품 (56.7\%)과 스킨케어 제품(37.1\%)에 대한 구매가 많았다고 하였
다. Park \& Kim (2008)은 쇼핑몰에서 화장품 구매 경험이 있 는 성인 여성들이 주로 구입하는 제품은 기초화장품(40.9\%), 색조화장품(20.4\%), 바디제품(11.3\%)이었으며, 화장품 전문 쇼 핑몰(32.7\%)보다 종합 쇼핑몰(66.0\%)을 더 이용하는 것으로 나타났다고 하여 이 연구의 결과와 차이가 있는데, 온라인을 통한 화장품 구매는 연구 시점과 조사대상자에 따라 구매 행태 에 차이가 있음을 알 수 있다.

\section{3. 온라인전용 브랜드 화장품의 만족도 구성요인}

온라인전용 브랜드 화장품의 만족도 구성요인을 알아보기 위

Table 2. Patterns of purchasing products of online-only brand cosmetics

\begin{tabular}{|c|c|c|c|}
\hline Categories & & Frequency & $\%$ \\
\hline \multirow{7}{*}{ Consideration } & Price & 33 & 16.5 \\
\hline & Quality and functionality & 142 & 71.0 \\
\hline & Design & 2 & 1.0 \\
\hline & Capacity & 6 & 3.0 \\
\hline & Aroma & 2 & 1.0 \\
\hline & Awareness & 10 & 5.0 \\
\hline & Convenience & 5 & 2.5 \\
\hline \multirow{4}{*}{$\begin{array}{l}\text { Same product purchase } \\
\text { propensity }\end{array}$} & I always buy new products & 22 & 11.0 \\
\hline & Sometimes, I buy another product & 95 & 47.5 \\
\hline & Usually, I buy the same product & 58 & 29.0 \\
\hline & I purchase a product that I have always used & 25 & 12.5 \\
\hline \multirow{6}{*}{$\begin{array}{l}\text { Annual average purchase } \\
\text { amount }\end{array}$} & Less than 50,000 won & 88 & 44.0 \\
\hline & Less than 100,000 won & 53 & 26.5 \\
\hline & Less than 200,000 won & 35 & 17.5 \\
\hline & Less than 300,000 won & 13 & 6.5 \\
\hline & Less than 400,000 won & 8 & 4.0 \\
\hline & Over 400,000 won & 3 & 1.5 \\
\hline \multirow{5}{*}{$\begin{array}{l}\text { Cosmetic online purchase } \\
\text { ratio }\end{array}$} & Less than $10 \%$ & 87 & 43.5 \\
\hline & Less than $10 \%$ to $30 \%$ & 67 & 33.5 \\
\hline & Less than $30 \%$ to $50 \%$ & 40 & 20.0 \\
\hline & Less than $50 \%$ to $70 \%$ & 4 & 2.0 \\
\hline & Not more than $70 \%$ & 2 & 1.0 \\
\hline \multirow{6}{*}{ A path to know } & Word of mouth & 7 & 3.5 \\
\hline & Magazines and newspapers & 10 & 5.0 \\
\hline & Internet (blogs and cafes) & 109 & 54.5 \\
\hline & Social networking service & 55 & 27.5 \\
\hline & Social commerce & 18 & 9.0 \\
\hline & Other & 1 & 0.5 \\
\hline \multirow{5}{*}{ Mainly purchased products } & Skin care & 56 & 28.0 \\
\hline & Cleansing product & 24 & 12.0 \\
\hline & Base make-up & 54 & 27.0 \\
\hline & Point make-up & 53 & 26.5 \\
\hline & Body makeup & 13 & 6.5 \\
\hline
\end{tabular}


해 주성분법과 Varimax 회전을 이용하여 탐색적 요인분석을 실시하였는데 요인 값이 여러 요인에 부하된 '결제방법과 처리 과정이 신뢰된다', '제품에 대한 충분한 정보가 제공된다', '고객 센터를 편리하고 신속하게 이용할 수 있다'의 3항목을 제외한 결과, 4 가지 요인이 추출되었다(Table 3 ; 설명량 $56.71 \%$ ).

제 1 요인은 '교환, 환불이 용이하다', '홈페이지 디자인에 만 족한다' 외 3문항으로 구성되어 서비스 및 품질로 명명하였다. 제 2 요인은 '다양한 종류의 상품이 구성되어 있다', '원하는 종 류의 다양한 제품을 구성하고 있다' 외 2 문항으로 구성되어 제 품 구색으로 명명하였고, 제 3요인은 '주문처리 및 배송관련 문 자나 이메일이 발송된다', '시간에 대한 구애를 받지 않고 구매 할 수 있다' 외 3 문항으로 구성되어 이용 편리성이라고 하였다. 제 4 요인은 '할인, 적립금 혜택이 많이 있다', '제품의 가격이 합 리적이다' 외 1문항으로 구성되어 경제성으로 명명하였다.

오프라인 매장과 관련된 선행연구에서 Kim \& Park (2005) 은 화장품 전문점에 대한 소비자의 만족도 요인이 판매원 및 점
포 분위기, 판매촉진, 가격, 광고 및 디자인으로 나타났다고 하 였고, Kim \& Roh (2008)는 저가 화장품의 구매만족도 요인이 품질, 가격, 매장, 직원이라고 하였다. 온라인전용 화장품의 경 우 서비스 및 품질이 제 1 요인으로 나타났으며, 판매원이나 매 장 요인 대신 이용 편리성이 만족도 구성요인으로 분류되어 차 이가 있음을 알 수 있었다.

\section{4. 온라인전용 브랜드 화장품의 만족도 평점}

온라인전용 화장품에 대한 각 요인별 만족도를 5 점 척도 로 알아본 결과(Table 4), 이용 편리성에 대한 만족도(3.68土

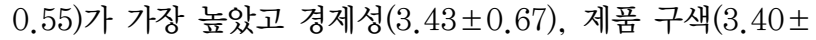
$0.60)$, 서비스 및 품질(3.33 \pm 0.57$)$ 순이었다. 온라인전용 화 장품은 이용 편리성에 대한 만족도가 다른 요인보다 매우 높았 는데, 이는 오프라인 화장품보다 시간과 공간에 구애 받지 않 고 구매할 수 있다는 것이 큰 장점으로 평가된다고 할 수 있다. 그러나 서비스 및 품질에 대한 만족도는 다른 요인에 비해 낮게

Table 3. Satisfaction factors of online-only brand cosmetics

\begin{tabular}{|c|c|c|c|c|}
\hline \multicolumn{2}{|c|}{ Factors } & Questions & $\begin{array}{c}\text { Factor } \\
\text { loading }\end{array}$ & $\begin{array}{l}\text { Variance } \\
\text { explained }\end{array}$ \\
\hline \multirow{5}{*}{1} & \multirow{5}{*}{ Service and quality } & Exchange and refund are easy & 0.74 & \multirow{5}{*}{$14.94 \%$} \\
\hline & & I am satisfied with the homepage design & 0.70 & \\
\hline & & The quality of the product is excellent & 0.69 & \\
\hline & & I am satisfied with product design and packaging & 0.62 & \\
\hline & & Delivery is fast and accurate after purchase & 0.49 & \\
\hline \multirow{4}{*}{2} & \multirow{4}{*}{ Assortment of products } & There are various kinds of goods & 0.78 & \multirow{4}{*}{$14.83 \%$} \\
\hline & & It is composed of various products that I want & 0.70 & \\
\hline & & It is easy to compare similar products & 0.69 & \\
\hline & & There are many buyer reviews & 0.67 & \\
\hline \multirow{5}{*}{3} & \multirow{5}{*}{ Convenience of use } & The order processing and delivery-related text or email is sent & 0.71 & \multirow{5}{*}{$14.40 \%$} \\
\hline & & One can buy without being concerned about time & 0.70 & \\
\hline & & It is convenient to connect to the website of an online-only brand cosmetics & 0.66 & \\
\hline & & Product order processing on the homepage is convenient & 0.51 & \\
\hline & & I can easily find the product I am looking for & 0.50 & \\
\hline \multirow{3}{*}{4} & \multirow{3}{*}{ Economics } & There are many discounts and reserved products & 0.79 & \multirow{3}{*}{$12.54 \%$} \\
\hline & & The product prices are reasonable & 0.74 & \\
\hline & & There are various events. & 0.67 & \\
\hline
\end{tabular}

Cumulative variance is $56.71 \%$

Table 4. Satisfaction with each factor for online-only brand cosmetics

\begin{tabular}{lll}
\hline Factors & Satisfaction \\
1 & Service and quality & $3.33 \pm 0.57^{1)}$ \\
2 & Assortment of products & $3.40 \pm 0.60$ \\
3 & Convenience of use & $3.68 \pm 0.55$ \\
4 & Economics & $3.43 \pm 0.67$ \\
\hline
\end{tabular}

${ }^{1)}$ S.D., mean \pm standard deviation; 5 point scale. 
평가되어 온라인 화장품의 질적인 면과 배송 및 교환 등의 서비 스에 대해 부족함을 느끼고 있음을 알 수 있었다.

\section{5. 온라인전용 브랜드 화장품의 재구매의도 영향요인}

온라인전용 화장품 브랜드의 만족도 구성요인이 재구매의 도에 영향을 미치는 영향을 알아보기 위하여 회귀분석을 실시 하였으며 그 결과는 Table 5 와 같다. 재구매의도는 '온라인전 용 화장품 브랜드에서 구매한 제품을 지인에게 추천할 것이 다', '다른 사람들에게 제품 구매 정보를 제공할 것이다', '가까 운 시일 내에 온라인전용 화장품 브랜드에서 제품을 구매할 것 이다', '내가 원하는 제품이 나온다면 적극 구매할 것이다', '온 라인전용 화장품 브랜드에 지속적인 관심을 둘 것이다' 5 항목 의 평균 점수로 평가하였다. 분석 결과 만족도 요인 중 이용 편 리성 요인이 재구매의도에 정(+)의 영향을 미치는 것으로 나타 났다. 이와 같은 결과는 온라인 화장품 브랜드를 조사, 구매하 는 과정에서 편리한 정도가 재구매로 이어질 수 있음을 의미한 다. 선행 연구에서 Park \& Kim (2008)은 온라인 종합몰, 전문 몰의 화장품 구매자들은 쇼핑몰 특성 중 편의성에 만족하였고 만족한 쇼핑몰은 다시 방문하고자 한다고 하여 이 연구의 결과 와 유사하였다.

\section{Conclusion}

이 연구는 온라인 쇼핑 이용률이 높은 20-30대 여성을 대상 으로 온라인전용 브랜드 화장품의 구매성향과 만족도, 재구매 의도 영향요인을 살펴보고자 하였는데 연구결과는 다음과 같 다.

첫째, 온라인전용 브랜드 화장품의 경우 기초, 색조 등 브랜 드의 주력 품목이 있는 경우가 많았으며 쉽고 특징적인 제품명 을 부각시키거나 다양한 이벤트를 활용하여 마케팅을 하였다. 온라인전용 브랜드 화장품의 인지도 조사결과, 브랜드는 삐아 가 가장 높은 반면 제품인지도는 라라베시의 악마쿠션과 악마 크림이 가장 높아, 브랜드의 인지도와 제품의 인지도가 다르게 나타났다. 또한, 온라인 판매 제품의 경우 홈페이지를 통한 판 매뿐 아니라 소셜커머스 등 다양한 판매처를 활용하고 있어 대
표제품을 부각시키는 마케팅을 활용하여 인지도를 높일 필요가 있으며 블로그, SNS 등을 통한 인터넷 홍보가 중요한 수단이 될 수 있으므로 이에 대한 전략이 필요할 것으로 생각된다.

둘째, 온라인전용 브랜드 화장품의 구매행태를 살펴본 결과 주로 기초화장품과 베이스 메이크업 제품을 구매하였고, 구매 시 품질과 기능을 중요시하는 것으로 나타났지만 온라인을 통 한 연평균 구매 금액이나 동일 제품 재구매 비율이 높지 않아 온라인전용 화장품의 경우에도 품질에 대한 신뢰를 높여 지속 적인 구매로 이어질 수 있는 방안이 강구되어야 할 것이다.

셋째, 온라인전용 브랜드 화장품의 구매만족도 구성 요인은 서비스 및 품질, 제품 구색, 이용 편리성, 경제성의 4 가지 요 인으로 나타났으며, 요인별 만족도를 비교한 결과 이용 편리성 의 평균 점수가 가장 높았다. 이러한 결과를 통해 서비스 및 품 질은 온라인을 통한 화장품 구매에 있어서도 중요한 차원임을 알 수 있었으나 다른 요인에 비해 구매만족도 점수가 가장 낮 았다. 따라서 온라인전용 브랜드 화장품의 품질에 대한 신뢰를 높이고 교환이나 환불, 정보제공 등의 서비스 부분에 만족을 높일 필요가 있다고 생각된다.

넷째, 온라인전용 브랜드 화장품의 재구매에 유의한 영향을 미치는 요인은 이용 편리성으로 나타났다. 온라인 브랜드 화장 품의 이용 편리성은 만족도가 높고 재구매의도에 유의한 영향 을 미치므로 홈페이지의 접근, 제품 검색에 대한 편리성을 높 이고 주문처리와 배송에 대한 정보를 즉각적으로 제공함으로써 고객의 만족도를 높이고 지속적인 구매로 연결할 수 있을 것이 다.

이 연구는 최근 확대되고 있는 온라인전용 브랜드 화장품을 구체적으로 비교하고 만족도와 재구매 영향요인을 파악하는데 의의가 있으나 조사대상자가 부산 및 경상남도 지역에 한정적 이고 온라인 브랜드의 특성상 제품의 종류가 다양하게 변화하 고 있다는 점이 한계라고 할 수 있다. 이 연구의 후속연구로 온 라인 오프라인 브랜드 화장품을 비교해보거나 대상자 특성에 따른 평가차이를 비교해볼 수 있을 것이다.

Table 5. Factors influencing intention to repurchase online-only brand cosmetics

\begin{tabular}{lccccc}
\hline Independent variable & $\mathrm{B}$ & $\mathrm{S} . \mathrm{E}$ & $\beta$ & $t$ & $F$ \\
Service and quality & 0.11 & 0.08 & 0.11 & 1.36 & $\mathrm{R}^{2}$ \\
Assortment of products & 0.04 & 0.07 & 0.03 & 0.04 & 10.60 \\
Convenience of use & 0.25 & 0.09 & 0.24 & $2.87^{* *}$ & \\
Economics & 0.12 & 0.06 & 0.14 & 1.83 & \\
\hline
\end{tabular}

$\mathrm{B}$, unstandardized coefficient; S.E, standard error; $\beta$, standardized coefficient; $t, t$-value; $F, F$-value; $\mathrm{R}^{2}$, correlation coefficient; ${ }^{* *} p<0.01$. 


\section{References}

An JH, Lee SJ. Market segmentation based on online fashion communities' behavioral types. Journal of the Korean Society of Costume, 65: 101-117, 2015.

Chun TY, Park NH, Park JS. The effect of purchase characteristics on positive emotion, relationship quality and repurchase in cosmetics on on-line shopping. Journal of Distribution and Management Research, 16: 121-131, 2013.

Hellier PK, Geursen GM, Carr RA, Rickard JA. Customer repurchase intention: a general structural equation model. European Journal of Marketing, 37: 1762-1800, 2003.

Ju EL, Ahn HS. A study on purchasing behavior of cosmetic consumers on the internet. Asian Journal of Beauty and Cosmetology, 8: 239-253, 2010.

Kim HJ, Rhee EY, Park JO. Consumer's purchasing process of fashion products on the internet: a qualitative approach. Journal of the Korean Society of Clothing and Textiles, 24: 907-917, 2000.

Kim JH, Ha JK. Purchase behavior and risk perception in cosmetics purchases at online shopping malls. Korean Journal of Human Ecology, 19: 1003-1012, 2010.

Kim KH, Oh SR. Methodology for applying text mining techniques to analyzing online customer reviews for market segmentation. The Journal of the Korea Contents Association, 9: 272-284, 2009.

Kim SW, Roh YL. The use satisfaction of low price cosmetics among female college students. Family and Environment Research, 46: 107-117, 2008.

Kim WR, Ko JM. A study on the effects of product attributes on the achievements of online shopping malls: with a focus on SOHO malls. The e-Business Studies, 17: 93110, 2016.

Kim YK, Park EJ. A difference in cosmetics evaluation criteria and consumer satisfaction according to life style: focused on women university consumers of cosmetics speciality store. Journal of the Korean Society of Cosmetology, 11:
26-33, 2005.

Lee JM. Effect of marketing stimulus of internet shopping mall on impulse buying, purchase satisfaction, and repurchase intention. Journal of the Korean Society of Cosmetology, 20: 735-742, 2014.

Lee MH, Kim HJ. A study on cosmetics purchase behavior and consumer dissatisfaction at internet shopping mall. Journal of the Korea Fashion \& Costume Design Association, 8: 87-100, 2006.

Lee $\mathrm{MH}$. Market segmentation of online and off-line cosmetics consumers according to benefits sought. Journal of the Korean Society of Clothing and Textiles, 32: 1034-1045, 2008.

Nam M. A study on the internet shopping behavior for fashion and beauty products according to lifestyle segmentation among female internet user. Journal of Digital Design, 14: 257-268, 2014.

Oh SJ, Lee SH. A study of college women's online shopping attitudes and cosmetics behavior. Journal of the Korean Society of Beauty and Art, 13: 121-137, 2012.

Park EJ, Kim JE. Relationships among shopping orientation, shopping-mall characteristics, consumer satisfaction, and loyalty in online market of cosmetics. The Research Journal of the Costume Culture, 16: 696-708, 2008.

Rosen KT, Howard AL. E-retail: gold rush or fool's gold? California Management Review, 42: 72-100, 2000.

Seo RS. Impact of online shopping mall attributes on shopping value, satisfaction, and loyalty of cosmetics consumers. Journal of the Korean Society of Cosmetology, 20: 455-462, 2014.

Shin MS, Kim HJ. A study of selection attribute and satisfaction for spectating online shopping mall. Journal of Distribution and Management Research, 17: 125134, 2014.

Szymanski DM, Hise RT. E-satisfaction: an initial examination. Journal of Retailing, 76: 309-322, 2000.

KOSIS (Statistics Korea, E-commerce trend survey), 2014. 02.25 . 


\section{국문초록}

\section{온라인전용 브랜드 화장품의 구매행태와 만족도}

김진아, 오윤경*

창신대학교 미용예술학과, 경상남도 창원시, 한국

목적: 이 연구는 온라인전용 브랜드 화장품의 판매 특성을 알아보고 소비자의 구매행태 및 만족도, 재구매에 영향을 미치는 요인을 파악함으로써 온라인 화장품 시장의 소비자 마케팅에 대한 기초자료를 제공하고자 한다. 방법: 조사 대상 브랜드는 키워드 검색과 인지도 조사를 통해 6개 브랜드를 선정하였고 홈페이지를 통해 판매특성을 분석하였다. 설문조사는 부산 및 경상남도 지역 20-30 대 여성 200명을 대상으로 화장품 구매 행태, 구매 만족도, 재구매의도 등을 조사하였다. 수집된 자료는 Statistical Package for the Social Sciences (SPSS) 통계프로그램을 사용하여 빈도분석, 기술통계, 요인분석, 회귀분석을 실시하였다. 결과: 첫째, 온라인전용 브랜드 화장품은 브랜드의 주력 품목이 있는 경우가 많았으며 쉽고 특징적인 제품명을 부각시키거나 다양한 이벤트를 활용하여 마 케팅을 하였다. 둘째, 온라인전용 브랜드 화장품의 구매행태를 살펴본 결과 주로 기초화장품과 베이스 메이크업 제품을 구매하였 고, 구매 시 품질과 기능을 중요시하는 것으로 나타났지만 온라인을 통한 연평균 구매 금액이나 동일 제품 재구매 비율이 높지 않았 다. 셋째, 온라인전용 브랜드 화장품의 구매만족도 구성 요인은 서비스 및 품질, 제품구색, 이용 편리성, 경제성의 4 가지 요인으로 나타났으며 이 중 이용 편리성은 구매 만족도가 가장 높았으며 재구매의도에 유의한 영향을 미쳤다. 결론: 온라인전용 브랜드 화장 품의 품질과 서비스에 대한 신뢰와 만족을 높일 필요가 있으며 홈페이지 접근, 주문 및 배송정보 등의 이용 편리성을 높여 재구매에 긍정적인 효과를 기대해볼 수 있을 것이다.

핵심어: 온라인전용 브랜드, 화장품, 구매행태, 재구매의도, 만족도

\section{참고문헌}

김근형, 오성열. 온라인 고객리뷰 분석을 통한 시장세분화에 텍스트마이닝 기술을 적용하기 위한 방법론. 한국콘텐츠학회논문 지, 9: 272-284, 2009.

김영경, 박은주. 라이프스타일에 따른 화장품 평가기준과 소비자 만족도에서의 차이: 화장품 전문점의 여대생 소비자를 중심 으로. 한국미용학회지, 11: 26-33, 2005.

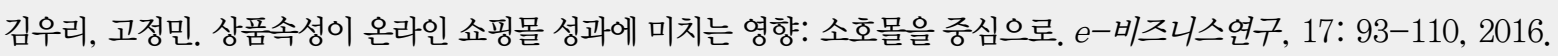
김주희, 하종경. 인터넷 쇼핑몰에서 화장품 구매시 위험지각에 따른 구매행동에 관한 연구. 한국생활과학회지, 19: 10031012, 2010.

김현정, 이은영, 박재옥. 인터넷을 통한 패션상품 구매행동의 탐색적 연구. 한국의류학회지, 24: 907-917, 2000. 남미우. 여성 인터넷 사용자의 라이프스타일에 따른 패션 및 뷰티 제품의 인터넷 쇼핑행동에 관한 연구. 디지털디자인학연구,

14: 257-268, 2014.

박은주, 김지은. 화장품 온라인 시장에서 쇼핑 성향, 쇼핑몰 특성, 소비자 만족, 충성도의 관계. 복식문화연구, 16: 696-708, 2008.

서란숙. 인터넷 쇼핑몰 속성이 화장품 소비자의 쇼핑가치, 만족도, 고객충성도에 미치는 영향. 한국미용학회지, 20: 455462, 2014.

신문식, 김효정. 온라인 쇼핑몰 업태별 선택속성과 만족에 관한 연구. 유통경영학회지, 17: 125-134, 2014. 안정희, 이수진. 온라인 패션 커뮤니티 행동 유형에 따른 시장 세분화. 복식, 65: 101-117, 2015. 오수정, 이수희. 여대생의 인터넷을 통한 화장품 구매행동 연구. 한국인체미용예술학회지, 13: 121-137, 2012. 이명희, 김현정. 인터넷 쇼핑몰에서의 화장품 구매행동과 소비자불만에 관한 연구. 한국의상디자인학회지, 8: 87-100, 2006. 
이명희. 추구혜택에 의한 온라인-오프라인 화장품 소비자의 시장세분화 연구. 한국의류학회지, 32: 1034-1045, 2008.

이정민. 인터넷 쇼핑몰의 마케팅 자극이 화장품 소비자의 충동구매, 구매만족도, 재구매의도에 미치는 영향. 한국미용학회지, 20: 735-742, 2014.

전태유, 박노현, 박종삼. 온라인 쇼핑에서 화장품의 구매특성이 긍정적 감정, 관계품질 및 재구매의도에 미치는 영향. 유통경 영학회지, 16: 121-131, 2013.

주은령, 안홍석. 인터넷 소비자의 화장품 구매행태에 관한 연구. 아시안뷰티화장품학술지, 8: 239-253, 2010.

KOSIS (통계청, 전자상거래동향조사), 2014.02.25. 


\section{中文摘要}

\section{网上品牌化妆品的购买行为和满意度}

金眞娥，吳允京*

昌信大学美容艺术学科, 庆尚南道昌原市, 韩国

目的: 通过分析网上化妆品品牌的销售特征, 确定影响消费者购买和回购模式的因素, 为网上化妆品市场消费者营销提 供基本信息。方法: 通过关键词搜索和认知度调查选出六个品牌, 并从其主页分析其销售特征。通过问卷调查, 调查了 釜山，庆尚南道20-30岁的200名女性的化妆品购买模式，购买满意度和回购意向。收集的数据通过 Statistical Package for the Social Sciences (SPSS)的统计软件进行频率分析, 技术统计, 因子分析, 回归分析。结果: 首先, 网上品牌化妆品 往往有品牌特色的产品, 通过简单和特色的产品名称或通过各种活动突出显示和销售。其次, 我们考察了网络化妆品品 牌的购买模式。研究结果显示: 主要购买彩妆和基础化妆品, 购买时比较重视产品品质和功能。但同一产品的平均购买 量或回购率较低。第三, 网上化妆品品牌购买满意度出现服务和质量, 产品分类, 易用性和经济性等四个组成因素。其 中, 易用性方面购买满意度显示最高, 对回购意向具有统计学意义的影响。结论: 必须提高网上化妆品的服务的信任和 满意度，提高访问网页的便利性，订购流程和交付信息，从而期待对回购有积极地影响。

关键词: 网上品牌, 化妆品, 购买态度, 回购, 满意度 